Relations industrielles

Industrial Relations

\title{
Hans Slomp, Labor Relations in Europe: A History of Issues and Developments
}

\section{Larry Haiven}

Volume 46, numéro 4, 1991

URI : https://id.erudit.org/iderudit/050724ar

DOI : https://doi.org/10.7202/050724ar

Aller au sommaire du numéro

Éditeur(s)

Département des relations industrielles de l'Université Laval

ISSN

0034-379X (imprimé)

1703-8138 (numérique)

Découvrir la revue

Citer ce compte rendu

Haiven, L. (1991). Compte rendu de [Hans Slomp, Labor Relations in Europe: A History of Issues and Developments]. Relations industrielles / Industrial

Relations, 46(4), 866-866. https://doi.org/10.7202/050724ar

Tous droits réservés @ C Département des relations industrielles de l'Universite Laval, 1991
Ce document est protégé par la loi sur le droit d'auteur. L’utilisation des services d'Érudit (y compris la reproduction) est assujettie à sa politique d'utilisation que vous pouvez consulter en ligne.

https://apropos.erudit.org/fr/usagers/politique-dutilisation/ 
Labor Relations in Europe: A History of Issues and Developments, by Hans Slomp, New York, Greenwood Press, 1990, 230 p., ISBN 0-313-26756-1

In writing this ambitious book which reviews nearly four centuries of European industrial relations in a mere 200 pages, the author has attempted to reconcile two major approaches. As he explains it, on the continent itself, descriptive nation studies and case studies have predominated. The Anglo-Saxon tradition, on the other hand, has stressed a more comparative and theoretical perspective. The one approach provides rich and colourful depictions of national idiosyncracies but often fails to provide a theoretical framework to understand parallel developments and regional variations. The other approach attempts to provide those frameworks but often pulls so far back in order to obtain such scope that important developments are ignored or missed. Yet both approaches have failed to do what political scientists and economic and social historians have done: develop a European view. Slomp takes this as his task.

To a certain extent the book reflects the advantages and disadvantages of both approaches. Its synoptic scope provides one of the few good single-volume reviews of the subject. And it is, after all, meant as a "general introduction to European labor relations for those who are unfamiliar with the subject". Yet this very breadth means that in every time period and for every substantive topic the author must skip at a maddening pace from country to country. Naturally, the larger and more influential countries, like Britain, France, Germany, the Scandinavians and (after 1917) the Soviet Union receive more attention than others. Yet many developments in the middle powers like Italy, Spain, Poland and the Netherlands cannot escape attention. Nor does the author fail to include significant events in smaller countries like Belgium, Greece, Bulgaria and Yugoslavia. In order to facilitate the task, he does define several "models" of labour relations emerging from each of the influential countries mentioned above. Yet these models are fragile. They come into prominence and fade at different times and the countries which "fit" these models have a nasty habit of pursuing their own private agenda from time to time. His approach works better the farther back in time he looks. For there is a wealth of secondary historical material on which to draw. The closer he comes to the modern era, the more shaky the work becomes.

Ironically for a book which must needs follow a chronological order, the best analyses are found where the author devotes effort to a specific theme. Some of the most interesting are found in discussions of such topics as new technology, clerical workers, women workers and the development of the welfare state and of worker participation in decision-making. Perhaps the most intriguing treatment is given to the ideological and political battles within trade union movements between socialists and anarcho-syndicalists (prior to World War I) and between social democratic and communist parties thereafter.

Despite its overall quality and self-imposed limitations, there are several annoying aspects to the book. Given that it is pitched strongly to an undergraduate-type audience, the presentation is dense and drab. The book could be improved by several visual aids such charts, graphs, tables and perhaps pictures. The book also does not contain footnotes of any sort. The author explains that he did this because "most of the text on each nation is probably more or less common knowledge in that particular nation". While there is a comprehensive bibliography organized by country, the lack of footnotes is frustrating to a North American. Should one wish to do further reading on a specific point or topic rather than a country, there is no assistance. And one suspects that the "knowledge" is not so "common" in particular nations as the author purports.

Larry HAIVEN 